\begin{tabular}{l}
\hline \hline GEOSPORT FOR SOCIETY \\
$\begin{array}{c}\text { GEOSPORT } \\
\text { SOCIETY }\end{array}$ \\
Scientific Journal founded in 2014 under aegis of University of Oradea (Romania), \\
University of Debrecen (Hungary), University of Gdánsk (Poland) \\
ISSN 2393-1353 \\
Edited by Oradea University Press \\
1, University Street, 410087, Oradea, Romania \\
Journal homepage: $h$ ttp://geosport.uoradea.ro/geosport.html
\end{tabular}

\title{
Levels of Public and Higher Education in Health Promotion in the Light of Focus Group Studies
}

\author{
Moravecz MARIANNA 1,2
}

1. University of Debrecen Doctoral School of Humanities Doctoral Program in Education and Cultural Sciences, Egyetem Square 1.4032 Debrecen, Hungary, e-mail: moraveczmarianna@gmail.com

2. University of Nyíregyháza, Sóstói Street 31 / B 4400 Nyíregyháza, Hungary, e-mail: moraveczmarianna@gmail.com

* Corresponding author

Citation: Marianna, M. (2019). Levels of Public and Higher Education in Health Promotion in the Light of Focus Group Studies. Geosport for Society, 11(2), 76-85. https://doi.org/10.30892/gss.1103-050

Article history: Received: 23.08.2019; Revised: 12.09.2019; Accepted: 20.10.2019, Available online: 14.11.2019

\begin{abstract}
Health is considered an upgrade value by The WHO Ottawa Charter for Health Promotion (1986), so we study the institutional role of these "upgrade values" from different points of view like roles, interests and representatives. We make our research both in the public and higher education also in the national and international field. In our comparative study we analyse the processes of the higher education in the context of the participants and we outline the conceps of the students. We made two focus group interviews with those students who took part in daily physical education and in their first year in the University of Debrecen and the University of Nyíregyháza. Each focus group contained 15 students who represented their own institutions. They also had to compare their health behaviour and sports practice in secondary school and university. Our research questions focused on the will to do something for health awareness (Pikó, 2002). We were curious about how the forms of developed health behaviour change entering the higher education and what the main motivations of health development are. Our results show that the students of both universities highlighted the institutional infrastructure, the teacher's attitude and most importantly the social effect of daily physical education.
\end{abstract}

Keywords: health improvement, public education, higher education, daily physical education

\section{Introduction}

Among the scenes of everyday life, educational institutions are places that have a long tradition of teaching a healthy lifestyle. Therefore, it is important that regular physical activity is treated by educational institutions as a value, to promote 
the development of a positive attitude towards movement and a commitment to an active lifestyle (Csányi, 2010). In view of this, school can be considered as one of the most important areas of health promotion (Somhegyi, 2012). In public education, there is an opportunity to develop the personality of students, where health and leisure time are valuable (Révész and Csányi, 2015). This is also true of higher education, although its institutional and pedagogical background is less developed.

\section{Literature review}

In our study, we wish to highlight, through the WHO Global School Health Initiative, that the roles of public and higher education in health education are fundamentally different. The three levels (following St. Leger, 2001) are:

- transfer of certain knowledge (eg self-assessment, body image);

- developing specific competencies (eg learning about typical health problems;

- developing certain social skills (eg caring for one's own health).

Students need to take the first two levels of public education. These first two levels are different from the third level because the acquisition of the knowledge contained therein greatly influences the individual's quality of life and outlook on life. Mastering the third, more complex level may be a task for higher education (as well as for secondary schools), so it is worth concentrating resources on developing social skills when organizing university programs. The most important pedagogical conclusion to be drawn from university programs is that the personal role of instructors is just as important as educating students, as any individual skills development program is doomed to failure in the absence of a supportive institutional environment.

Although there are many similarities between schools and universities in health promotion, the two environments are fundamentally different. Among the most important differences are:

- from a legal point of view, in many cases schoolchildren are not yet of legal age, so in many cases smoking and alcohol consumption can be an offense, making it difficult to deal with the issues honestly;

- the role of the family in students is typically greater than in many cases away from home;

- sexual activity is - at best - completely different for the two groups, but these boundaries are increasingly blurred;

- the role of teachers and trainers in modeling varies significantly: while personal leadership and support are much more important in schools, the distance between the two groups is greater at universities, so basically other methods are needed.

Perhaps the main difference between the two scenes is that while at school the individual is at the center of health promotion, universities (which in principle 
prepare students for socio-economic leadership roles) need to make everyone aware that the knowledge they have acquired it can influence not only individual quality of life but also the lives of a narrower and wider community (St. Leger, 2001).

All countries strive to ensure that healthy young people leaving higher education serve as a positive role model for other sections of society, and that higher education can provide an opportunity for higher education as a last resort. The university should be considered as a theater, because students live their everyday lives, study and work here (Barabás, 2013). Scene approaches date back many years. The Ottawa Charter (WHO, 1986) focuses on a health-promoting environment, and the Jakarta Declaration (WHO, 1997) emphasizes the value of the scene as health promotion strategies can only be realized under the right environmental conditions. The first and best known program based on color space, the so called. "Healthy cities" became a popular movement worldwide (Tsouros et al., 1998). Subsequently, the "health education schools" movement became known. The transfer of this idea to higher education in the UK is associated with Dooris et al., (Dooris, 2006).

Based on these documents, the University of Health Development is an institution that integrates health into its culture as an organizing value. The institution protects the health of educators and students, as well as the well-being of the wider community. Health is an important part of university plans and university policy. Such a university creates and maintains a healthy physical environment in which workplaces that promote health and have a positive impact on those who work there are created; at the same time, they promote students' healthy personal development and social relationships.

On the university scene, problematic issues are grouped around different topics:

- drug and alcohol consumption: Strict regulation and counseling for users is a priority;

- sexually Transmitted Diseases: As universities are predominantly young people who are getting out of close parental care for the first time in their lives, this area is inevitable;

- mental health and well-being: relatively little data and research is available on students. It is primarily due to the reduction of drop-out rates and the need for this area of intervention;

- exercise and healthy eating: An important part of education for a healthy lifestyle is the development of appropriate physical activity and physical education, and the promotion of healthy eating where universities can play an important role (Baidog and Herman, 2018; Dooris and Doherty, 2009; Papp et al., 2019; Tătar et al., 2018; Zadarko et al., 2011). 


\section{Material and methods}

In our study, we attempt to conduct exploratory research using focus group interviews, thus interpreting the process of transition from public education to higher education in the context of stakeholders. We wanted to grasp the nodes along which the students interpret the influences they understand within the framework of health promotion within the subject of physical education (everyday physical education).

In the spring of 2017, we interviewed 7 students from the University of Nyíregyháza (hereinafter referred to as NY), then 8 students from the University of Debrecen (hereinafter DE), totaling 15 students. The focus groups consist of male and female students who entered tertiary education during their first year of high school and were involved in the health promotion program of daily physical education. The focus groups are distinguished by the student status of the two institutions and the degree programs they choose. During the interviews the atmosphere of the groups was relaxed. The students were happy to tell about their experiences. As the given study population and institution have not yet been examined from this point of view, no concrete hypotheses have been formulated, rather we have focused on research questions.

The main questions of our exploratory research for the already implemented health promotion program (daily physical education):

1. What is the (negative / positive) impact of day-to-day physical education among students in public education?

2. How do the forms of health behavior developed in public education change in the values of students entering higher education?

3. What are some of the main motivational factors that can be a supporting factor in health promotion?

\section{Results}

1. The impact of daily physical education

In order to improve the health of students and a healthy lifestyle, in line with the principles of comprehensive school health promotion in Hungary, CXC 2011 on national public education Act 5 provides for the daily, that is five weekly, physical education classes in all grades, the implementation of which began in September 2012. This created an opportunity for our institutions to make a significant contribution to the regular physical activity and physical activity of school-age children. In 2016, the first year of graduation in higher education came to attend this program during high school.

As a research question, what were the effects of day-to-day physical education on the students involved? 
We are unable to provide a clear answer to the question we are asking, but we do try to outline decisive directions along some points based on students' opinions.

On the positive side, the serious community-building power of everyday physical education was highlighted. Community and team games were emphasized most:

"I loved the body so much; it was the last year that we were able to work as a team, whatever the sport." (DE boy)

The importance of contemporary communities has already been pointed out in the literature (Pusztai, 2011). Sport enables students to acquire the skills they need to become successful in their lives (such as social skills, collaboration, problem solving, openness to society, social roles, etc.), and positively influences academic achievement overall (Gordon and Caltabiano, 1996; Serbu, 1997; Kovács, 2015).

The same opinions were emphasized in both institutions as a negative effect.

"In the last two years before graduation, there was a lot of pressure on learning and it was not what we wanted we go to volleyball, but we had to run 8 laps. I would change it to do the kids what they want." (DE girl)

They fundamentally agree with the principle of day-to-day physical education, but see it as problematic due to lack of room and overcrowding.

"Because it was every day, many classes had a class at the same time, so there were 3-4 classes in the same room at the same time, so we could play 5 minutes of the 45 minute class." (NYE boy)

"Many times, in the hallway or in smaller halls, the clock was as healthy as it would have been." (DE boy)

To the question of whether compulsory physical education should be introduced in universities, similar to everyday physical education? Various answers were provided by DE and NYE students.

"I would support the introduction because if, for example, we are based on a medical university where I have a lot of acquaintances, I see them ready; they have no time for anything. If sports were compulsory at least 1-2 times a week, they would have the opportunity to do something other than studying." (DE boy)

"No, because there are a lot of students who learn a lot and maybe need sports, but they are not required. Rather, it should be motivation, interest, attention, new opportunities." (NYE boy)

At the university, the proportion of regular sports is drastically decreasing, which is often attributed to the lack of time and the high demands and inflexibility of the university education system. This phenomenon is also difficult to investigate because shifts in students' knowledge, competences, and personality occur during the youth phase (Zinnecker, 1993), when personality traits, worldviews, and thinking 
exhibit plasticity. Thus, the process is also related to changes in age. Inglehart's (2008) research, for example, illustrates the effect of age on value preferences.

\section{Changes in health behaviors in higher education}

Elements of a healthy lifestyle and forms of health behavior are influenced by many factors. Such a factor is age: movement is still an integral part of a child's life (Keresztes et al., 2003), but over time it shows a decreasing tendency (Sallis, 1993). The activity decreases significantly even in young adulthood, because during this phase of life significant changes and life events occur (beginning of independent life) (Goldscheider et al., 1993). Our next research question focuses on this stage of life.

How do the health behaviors of public education change in the values of students entering higher education?

Students are not health conscious. They mainly refer to the lack of time, the university lifestyle:

"I have no time to exercise, no healthy eating, no regular meals, sometimes I forget to eat, so I eat late. Today, for example, I'll be in college from 8am to 8pm." (DE girl)

DE and NYE students have all met some of the noxious passions in high school. It changes which one: which is the least with drugs, most with cigarettes and alcohol. They remove the subject: the "others" did it. The importance of teacher patterns is also articulated.

"We had smoking and alcohol, but after 9 th grade. It was not a good example that we saw the same thing from the educators. We were disturbed when they came to the class that we could smell the cigarette." (DE girl)

Students see sport as a general value, but they do not always have the time. DE students, due to lack of time due to university education, do not exercise:

"If I had time, I'd sacrifice anything." (DE boy)

"Today's education system does not allow time for sport" (DE girl)

NYE students have a very positive attitude, they spend more money and time, they are the more athletic focus group.

"Sport is very valuable to me, and I like to spend time doing it, and if it comes to making money, even joining an association, it will require some money. If you want to gain muscle mass, or any improvement, you need to change your life, your diet, or your diet, and that has some financial implications. I appreciate it and if I can, I will sacrifice it." (NYE boy)

Our interviews also confirmed the findings of previous research that: Sport is an active form of health behavior that requires conscious energy investment and conscious control (Pikó and Keresztes, 2007; Dragos et al., 2017). In this case, I would highlight awareness as an important factor. 
In terms of health behavior, the mindset of the Conscious Thinking Group (NYE) and its positive lifestyle and nutritional habits were distinguished from those of high school. Thus, the extent to which the individual and the system itself are able to evolve at several levels in an increasingly conscious direction may be the key to success (Orosz and Jónás, 2017).

There are many factors that influence risk-taking behavior. With a positive commitment to sport, it may be easier to withstand the negative, "party" peer pressure almost expected on campus. Here, too, awareness, the specific purpose of life, plays a role. "I'm in the Airplane Program, both for parental support and for my childhood dream." (NYE boy)

3. The main motivational factors of health promotion

As a final issue of our qualitative research, we looked for the main motivational factors that may be a supporting factor in health promotion.

Students attributed a high priority to institutional sports infrastructure and focused on experience-based sport. (Volleyball, aerobics, TRX, kettleball, yoga, meditation, various dances are the favorite sports for students).

Similarly, to public education, the role of physical education plays a key role in higher education. Although personalized relationships between educators and students are increasingly disappearing in a massively expanding higher education system, especially in thousands of students, we can see that a student-friendly, empathetic, curious physical education teacher can exert an enormous impact on students' health and within the context of regular sport education (Kovács and Moravecz, 2019).

"The two teachers I contact today still came in and said they were doing their heart and soul, they loved what they were doing, not giving them this lesson and something, they have to do it, but they don't feel like it, they have more things to do." (NYE boy)

Nagy et al., (2017) formulated the following tasks for higher education:

"The generation of day-to-day physical education offers new opportunities for university physical education and sports." The authors say a service-oriented, modern inclusive education has evolved, where the role of the teacher is valued and coaching has become a tool for efficiency. The task of the Physical Education Departments has been to introduce a student-friendly pedagogy that is consistent with student activation and successful education.

The most important supporting factor is the community, where students can gain benefits in several areas during their higher education years.

"I really liked high school gym classes. It was five times a week, we played volleyball, we played basketball, and it really took off in the last few years, the mood was really good, everyone loved it, the whole class." (DE girl) 
As a member of a sports community, participating in sporting activities brings many benefits to the individual, as it contributes to social and emotional development, as well as improving the individual dimension of student well-being and psychological well-being. It improves external appearance, social skills, position of control (ie the person's reference point), academic performance, and leads to sports success and helps to accept the structure of positions in the team (Taliaferro et al., 2010; Kovács, 2014).

\section{Findings}

In our study, we sought to identify the key drivers that can influence students entering public education from higher education to lead healthier lives. Our qualitative study sought to outline the effects of day-to-day physical education on them.

Based on our results we can say that from the point of view of high school and higher education health behavior students of both universities emphasized the institutional sports infrastructure, the teacher attitude and the most important value of high school every day physical education (Kovacs and Moravecz, 2017).

Everyday physical education plays a fundamental role in the development of lifelong exercise-rich lifestyles. During the school years, the emphasis is placed on the acquisition of competences that can be incorporated into the individual's daily life after leaving public education. The long-term value of the program can be realized if there are supply options available at different stages of the exodus from the sport, such as leaving the education system or entering the workplace, life stage, resuming a mobile lifestyle or re-joining (Perényi and Bodnár, 2015). It became necessary to get a clearer understanding of the values of the stakeholders and the learners; which factors could play the most important role in their decisions and in the management of their actions. However, this system of values is constantly changing and is affected by several factors. The most important of these is age contemporaries, gender, type of sport. The values of the youth populations are clearly shifting the experience towards central, postmodern values, which tendencies are confirmed not only by domestic but also international large-scale value studies (Inglehart and Baker, 2000; Schwartz et al., 2000). Schulze (2000) talks about an experience society, which emphasizes autonomy, freedom of choice, and the search for experience and diversity.

Further research is needed on the fact that by 2024 higher education will reach the age group who will be 12 years old (the whole public education process) behind their daily physical education. From an early age, you may be involved in frequent physical activity. How will the development of health education in higher education change by 2024 to meet the experience-oriented demands of the age? 


\section{References}

Baidog, A., \& Herman, G. V. (2018). The Influence of Sports and Physical Activity on the Metabolic Syndrome: A Systematic Review. Analele Universităţii din Oradea Facicula Educaţie Fizică şi Sport, 28, 39-45.

Barabás K. (2013). Health promotion in higher education. In: Tarkó K.-Lippai L. (Szerk.): „Fruit? The tree will redeem what it promised with the flower." Studies for the 60th birthday of Zsuzsanna Benkő. Pp. 277-293. Szeged: SZTE JGYPK (In Hungarian)

Csányi T. (2010). Characteristics of young people's physical activity and inactive activities. Új Pedagógiai Szemle, 3-4. 115-129 (In Hungarian)

Dooris, M. (2006). Healthy settings: challenges to generating evidence of effectiveness. Health Promotion International, 21(1), 55-65.

Dooris, M., Doherty, S. (2009). National Research and Development Project on Healthy Universities: Final Report. University of Central Lancashire, Preston.

Dragoș, P. F., Szabo-Alexi, M., Szabo-Alexi, P., Ilieș, D. C., Gozner, M., Marcu, F., C. Iovan, C., Buhaş, S., Pop, A. C., Dumbravă, R., \& Stance, L. (2017). Investigations concerning the influence of sports trainings carried out in a protected area (Natura 2000 site) on various physiological and biological parameters for athletes. GeoSport for Society, 6 (1), 40-46.

Goldscheider, F., Thornton, A., \& Young-DeMarco, L. (1993). A portrait of the nest-leaving process in early adulthood. Demography, 30(4), 683-699.

Gordon, W. R., \& Caltabiano, M. L. (1996). Urban-rural differences in adolescent self-esteem, leisure boredom, and sensation-seeking as predictors of leisure-time usage and satisfaction. Adolescence, 31(124), $883-901$.

Inglehart, R. F. (2008). Changing values among western publics from 1970 to 2006. West european politics, 31(1-2), 130-146.

Inglehart, R., \& Baker, W. E. (2000). Modernization, cultural change, and the persistence of traditional values. American sociological review, 65 (1), 19-51.

Keresztes, N., Pluhár, Z., \& Pikó, B. (2003). A fizikai aktivitás gyakorisága és sportolási szokások általános iskolások körében [Frequency of physical activity and sports habits among primary school students]. Magyar Sporttudományi Szemle, 4(4), 43-47 (In Hungarian).

Kovács K., Moravecz M. (2019). Role of Higher Education Institutions in Lifelong Sports Socialization of Students - Health Promotion Practices in the Carpathian. In Juhász, E., Endrődy, O. (szerk.) Education-Economy-Social Budapest, Magyarország: Debreceni Egyetem, Magyar Nevelés- és Oktatáskutatók Egyesülete (HERA), (2019) pp. 540-558.,19 p. (In Hungarian).

Kovács, K. (2014). Boldogító mozgás. A sportolás hatása a partiumi hallgatók szubjektív jóllétére, lelki edzettségére és egészségének önértékelésére [Blissful moving: The effect of sports on the subjective well-being, mental health, and self-esteem of party students]. Kapocs, 2, 2-13 (In Hungarian).

Kovács, K. (2015). A sportolás mint támogató faktor a felsőoktatásban [Sport as a supporting factor in higher education]. Oktatáskutatók könyvtára, 2 (In Hungarian).

Kovács, K., Moravecz, M. (2017). Kárpát-medencei hallgatók sportolási szokásai és ennek intézményi környezete a felsőoktatásban [Sporting habits of Carpathian Basin students and its institutional environment in higher education]. In: Kerülő J., Jenei T., Gyarmati I. (szerk.) XVII. Országos Neveléstudományi Konferencia. 636 p. (In Hungarian).

Nagy, Á., Fintor, G., Urbinné Borbély, Sz. (2017). Az egyetemi testnevelő tanárok tevékenységprofiljára ható testkulturális változások [Physical Education Changes Affecting University Physical Education Teachers' Activity Profile]. In: Kovács K. (szerk.) Értékteremtő testnevelés Tanulmányok a testnevelés és a sportolás szerepéről a Kárpát-medencei fiatalok életében (In Hungarian).

Orosz, R., Jónás, P. (2017). Új generáció - új szemléletek a sporttehetség-gondozásban Értékteremtő testnevelés [The New Generation - New Approaches to Sports Talent Management Value-creating Physical Education]. In: Kovács K. (szerk.) Tanulmányok a testnevelés és a sportolás szerepéről a Kárpát-medencei fiatalok életében (In Hungarian). 
Papp, B.M., Șerbescu, C., Caciora, T., Baidog, A., Olău, V. M. (2019). The Effects of a Physical Activity Program on Body Composition and Physical Condition in the Overweight Adult. Analele Universităţii din Oradea Facicula Educaţie Fizică şi Sport, 29, 1-9.

Perényi S. - Bodnár I. (2015). Sports Clubs in Hungary. In Breuer, C., Hoekman, R., Nagel, S. \& van der Werff, H. (eds.), Sport Clubs in Europe. A cross-national comparative Perspective (pp. 221-247). Basel: Springer International Publishing.

Pikó, B. (2002). Egészségtudatosság serdülókorban [Health awareness in adolescence]. Budapest: Akadémiai (In Hungarian).

Pikó, B., Keresztes, N. (2007). Sport, lélek, egészség [Sport, Soul, Health]. Budapest: Akadémiai (In Hungarian).

Pusztai, G. (2011). A láthatatlan kéztől a baráti kezekig [From invisible hands to friendly hands]. Budapest: Új Mandátum (In Hungarian).

Révész, L., Csányi, T. (2015). Tudományos alapok a testnevelés tanításához I. kötet: szemelvények a testnevelés, a testmozgás és az iskolai sport tárgyköréből. Társadalom-, természet- és orvostudományi nézőpontok [Scientific Basics for Teaching Physical Education Volume I: Excerpts from Physical Education, Physical Education and School Sports. Viewpoints in social, natural and medical sciences]. Budapest: Magyar Diáksport Szövetség (In Hungarian).

Sallis, J. F. (1993). Epidemiology of physical activity and fitness in children and adolescents. Critical reviews in food science and nutrition, 33(4-5), 403-408.

Schulze, G. (2000). Élménytársadalom. A jelenkor kulturszociológiája. A mindennapi élet esztétizálódása [Adventure Society. The sociology of contemporary culture. The aestheticization of everyday life]. Szociológiai Figyelö, 1(2), 135-157 (In Hungarian).

Schwartz, S. H., Bardi, A., \& Bianchi, G. (2000). Value adaptation to the imposition and collapse of communist regimes in East-Central Europe. In Political psychology (pp. 217-237). Palgrave Macmillan, London.

Serbu, J. (1997). Effect of college athletic participation on later life satisfaction and job satisfaction. College Student Journal, 31(2), 261-271.

Somhegyi, A. (2012). Elements contributing to the full implementation of comprehensive school health promotion at national level in Act CXC of 2011 on National Public Education. Népegészségügy, 9, 3. szám, 202-213. (In Hungarian)

St Leger, L. (2001). Schools, health literacy and public health: possibilities and challenges. Health promotion international, 16(2), 197-205.

Taliaferro, L. A., Rienzo, B. A., \& Donovan, K. A. (2010). Relationships between youth sport participation and selected health risk behaviors from 1999 to 2007. Journal of school health, 80(8), 399-410.

Tătar, C. F., Herman, G. V., \& Pețan, P. (2018). Sport and physical activity engagement in Romania. Geosport for Society, 8(1), 40-50.

Tsouros, A., Dowding, G., Thompson, J., Dooris, M., \& World Health Organization. (1998). Health Promoting Universities: Concept, experience and framework for action (No. EUR/ICP/CHVD 0309 01). Copenhagen: WHO Regional Office for Europe.

World Health Organisation (1986). The Ottawa Charter for Health Promotion. International Conference on Health Promotion. Ottawa, 1986. november 17-21. In: Principles of health promotion. Basic international documents for health promotion. Pp. 9-14. Budapest: Országos Egészségfejlesztési Intézet (In Hungarian).

World Health Organization, WHO (1997). Jakarta declaration on Health promotion into the $21^{\text {st }}$ Century, WHO Regional Office for Europe, Copenhagen, 1997.

Zadarko, E., Barabasz, Z., Szabo-Alexi, P., Szabo-Alexi, M., Suciu, A., Stef, M., Santa, C. (2011). Physical education and students' health promotion platform as an element of European Union's health strategy against the level of cardiorespiratory fitness of students from Poland, Slovakia, Romania. Studia Universitatis Babes-Bolyai, Educatio Artis Gymnasticae, 56 (3), 107-116.

Zinnecker, J. (1993). A fiatalok a társadalmi osztályok terében [Young people in social classes. In: Gábor K. (Szerk.): Change of civilization era and youth]. Civilizációs korszakváltás és ifjúság, 5-29 (In Hungarian). 